\title{
Simulation of Substrate, Microbial Interaction with Recycle using MATLAB Computational Approach
}

\author{
C. P. Ukpaka, S. Orike, and F.U. Igwe
}

\begin{abstract}
This research outlines the microbial and substrate interaction in a plug flow bioreactor system for effective utilization of the substrate by the microorganism. To achieve this mathematical models were developed to monitor, predict and simulate the interaction characteristics of the bioreactor using the functional parameters for interaction of microbial and substrate concentration in a plug flow reactor system. The MATLAB computer program language was used to determine the interaction relationship between the substrate and microbial concentration upon the influence of bioreactor volume, space time and discharge time. The characteristics of the behavior in terms of decrease in substrate concentration with increase in microbial concentrate revealed the interaction in the bioreactor with recycle.
\end{abstract}

Index Terms-Computational approach, MATLAB, Microbial, Recycle, Substrate

\section{INTRODUCTION}

In microbial and substrate interaction processes in which enzyme-substrate complex disintegrate and products are produced by the activity of the cells mass in the substrate has yielded good result in either environmental clean-up in manufacturing process [1]. The process leads to the formation of useful products, as well as substance that are environmentally friendly such as the desired product biomass, heat and gases released [2]. The main concept of interaction is basically on the ability of the microbes to degradate the substrate without inhibiting influence from the environment [3]. In this case, when the bioreactor system is not inhibited, there is tendency of the high microbial and substrate interaction in process leading to absent of lag phase as well presence of acceleration and progressive phase and the utilization of the substrate will be at optimum [4]

When the stationary phase is achieved in the bioreactor and in this case substrate utilization remain constant [5]. Most of the products achieved during this processes are useful in beverages, remediation of polluted environment, drugs, alcohol production etc [6]. Investigation conducted on the usefulness of microorganism in enhancing national development has proved positive, indicating the great achievement in the world of science and technology.

In the microbial, substrate interaction, the metabolites of

Manuscript published July 31, 2016.

C. P. Ukpaka is with the Department of Chemical/Petrochemical Engineering, Rivers State University of Science and Technology, Nkpolu, PMB 5080, Port Harcourt, Nigeria (e-mail: chukwuemeka24@yahoo.com).

S. Orike is with the Department of Electrical/Computer Engineering, Rivers State University of Science and Technology, Nkpolu, PMB 5080, Port Harcourt, Nigeria (e-mail: orike.sunny@ust.edu.ng).

F. U. Igwe is with the Department of Biochemistry, Rivers State University of Science and Technology, Nkpolu, PMB 5080, Port Harcourt, Nigeria (e-mail: fuigwe@ hotmail.com). the primary and secondary products are formed as reviewed by various research groups [7]-[11]. Research conducted revealed that the significance of secondary concept of metabolites can be related or identified upon influence microorganisms' activities [12] as well as its hazardous characteristics in the system [13]. The recent investigation in the production of enzymes by the mechanisms of a bioreactor has shown a great advantage over other technologies that has been in practice for years [14].

In most processes of biochemical reactions for effective enzyme substrate complex formation the disintegration of it yields products that are environmental friendly and in most cases, the bioreactor is modified by the application of compounds that is added to the bioreactor to improve the fermentation process which order wise referred to as biotransformation [15]. Research conducted revealed the concept of microbial and substrate interaction as well as biomass increase in a favorable conditions and the transformation mechanism of raw materials by the application of microorganism [11]. It is revealed that the application of biotransformation can result to low energy level especially when nutrients added, acts as a rate limiting agent [16]. Microbial and substrate interactions are influenced by various components such as physicochemical properties of the process under investigation [17]. For effective controlling of a bioreactor, the following concepts must be put into consideration during the design for effective optimum of the characteristics of process [18]. The aim of the research is to ascertain the microbial and substrate interaction using MATLAB to monitor, predict and simulate the microbial and substrate utilization in a bioreactor.

\section{MATERIALS AND MethodS}

The general material balance expression for microbial and substrate interaction is given in (1) as:

Material input + Formation by Biochemical reaction - Material output=Accumulation

Material Balance in terms of Biomass (X)

Where the rate of reaction $\mathrm{R}=$ Velocity $\mathrm{V}$, therefore the mathematical expression for each of functional parameter is expressed as:

Input $=\left(\mathrm{F}_{\mathrm{O}}+\mathrm{F}_{\mathrm{R}}\right) \mathrm{X}$

Output $=\left(\mathrm{F}_{\mathrm{O}}+\mathrm{F}_{\mathrm{R}}\right)(\mathrm{X}+\mathrm{dX})$

Formation by Biochemical reaction $=\mathrm{R}_{\mathrm{X}} \mathrm{Dv}$

Accumulation $=\frac{d X}{d t} \mathrm{~V}$ 
Substituting (2), (3), (4) and (5) into (1) we have:

$\left(F_{O}+F_{R}\right) X+R_{X} d V-\left(F_{O}+F_{R}\right)(X+d X)=(d X / d t) V$

Considering $d V=a_{c} d z$, as well as steady state (1) and rearranging we have:

$\mathrm{R}_{\mathrm{X}} \mathrm{a}_{\mathrm{c}} \mathrm{dz}=\left(\mathrm{F}_{\mathrm{O}}+\mathrm{F}_{\mathrm{R})}(\mathrm{dX})\right.$

Considering the recycle ratio $\mathrm{R}=\frac{F R}{F o}$ therefore $\mathrm{F}_{\mathrm{R}}=\mathrm{RF}_{\mathrm{O}}$,

$\mathrm{R}_{\mathrm{X}} \mathrm{a}_{\mathrm{c}} \mathrm{dz}=\mathrm{F}_{\mathrm{O}}(1+\mathrm{R}) \mathrm{Dx}$

Separating the variables of (8) as well integrating, we have:

$$
\frac{\mathrm{acdz}}{\mathrm{Fo}(1+\mathrm{R})}=\frac{d X}{R x}
$$

Integrating (9) using the following boundary conditions, thus:

At $\mathrm{t}=0, \mathrm{Z}=0$ to $\mathrm{z}, \mathrm{X}=\mathrm{X}_{\mathrm{A}}$ to $\mathrm{X}_{\mathrm{c}}$

$\frac{\mathrm{ac}}{\mathrm{Fo}(1+\mathrm{R})} \int_{0}^{Z} d Z=\int_{X A}^{X e} \frac{d X}{R X}$

Similarly, for the Substrate, the form is also expressed as:

$\frac{\mathrm{ac}}{\mathrm{Fo}(1+\mathrm{R})} \int_{0}^{Z} d Z=\int_{S A}^{S e} \frac{d s}{R S}$

Taking a material balance for the substrate about the point of the mixing of the fresh feed and the recycle stream gives:

$\mathrm{S}_{\mathrm{o}} \mathrm{F}_{\mathrm{o}}+\mathrm{S}_{\mathrm{R}} \mathrm{F}_{\mathrm{R}}=\left(\mathrm{F}_{\mathrm{o}}+\mathrm{F}_{\mathrm{R}}\right) \mathrm{S}_{\mathrm{A}}$

$\mathrm{S}_{\mathrm{A}}=\frac{S O F O+S R F R}{F O+F R}$

$\mathrm{S}_{\mathrm{A}}=\frac{S O F O+S R F O R}{\text { Fo+FoR }}$

$\mathrm{S}_{\mathrm{A}}=\frac{S o+R S R}{1+R}$

Similarly, for the biomass, we have:

$X_{o} F_{o}+X_{R} F_{R}=\left(F_{o}+F_{R}\right) X_{A}$

$\mathrm{X}_{\mathrm{A}}=\frac{X o F o+X R F R}{F o+F R}$

If $\mathrm{X}_{\mathrm{R}}=\sum \mathrm{Xe}$

$\mathrm{X}_{\mathrm{A}}=\frac{X o F o+\sum X e F o R}{F o+F o R}$

$\mathrm{X}_{\mathrm{A}}=\frac{X o+\sum X e R}{1+R}$

Equations (12) and (13) define the boundary conditions on (11) and (10).

Recalling (11) we have:

$\frac{\mathrm{ac}}{\mathrm{Fo}(1+\mathrm{R})} \int_{0}^{Z} d Z=\int_{S A}^{S e} \frac{d s}{R S}$
Recall that for Monod's kinetics and Discharge Coefficient, the reaction rate with respect to the substrate Rs may be defined as:

$\mathrm{Rs}=\frac{-U m S X a}{(K s+S) Y}$

Substituting Rs into (11), we have:

$\frac{\mathrm{ac}}{\mathrm{Fo}(1+\mathrm{R})} \int_{0}^{Z} d Z=\int_{S e}^{S A} \frac{(K s+S) Y d s}{S X a U m}$

$\frac{\mathrm{ac}}{\mathrm{Fo}(1+\mathrm{R})} \int_{0}^{Z} d Z=\frac{Y}{\text { XaUm }} \int_{S e}^{S A} \frac{(K s+S) d s}{S}$

$\frac{\mathrm{acXaUm}}{\mathrm{Y} \mathrm{Fo}(1+\mathrm{R})} \int_{0}^{Z} d Z=\int_{S e}^{S A} \frac{K s d s}{S}+\int_{S e}^{S A} d s$

Let $\mathrm{S}_{\mathrm{A}}=\mathrm{S}_{\mathrm{I}}$. Integrating the above equation gives:

$\frac{\mathrm{acXaUmZ}}{\mathrm{Y} \mathrm{Fo}(1+\mathrm{R})}=\mathrm{K} \ln \frac{S i}{S e}+\left(\mathrm{S}_{\mathrm{I}}-\mathrm{Se}\right)$

The definition of the Discharge Coefficient $\mathrm{Y}=\frac{X e-X i}{S i-S e}$ can be used to derive an expression for the Biomass concentration by substituting $\mathrm{Y}=\frac{X e-X i}{S i-S e}$ into (14).

$\frac{\operatorname{acXaUmZ}(\mathrm{Si}-\mathrm{Se})}{\mathrm{Fo}(1+\mathrm{R})(\mathrm{Xe}-\mathrm{Xi})}=\mathrm{Ks} \ln \frac{S i}{S e}+\left(\mathrm{S}_{\mathrm{I}}-\mathrm{Se}\right)$

$\frac{\operatorname{acXaUmZ}(\mathrm{Si}-\mathrm{Se})}{\mathrm{Fo}(1+\mathrm{R})}=(\mathrm{Xe}-\mathrm{Xi}) \mathrm{Ks} \ln \frac{S i}{S e}+\left(\mathrm{S}_{\mathrm{I}}-\mathrm{Se}\right)(\mathrm{Xe}-\mathrm{Xi})$

$\frac{\operatorname{acXaUmZ}}{\mathrm{Fo}(1+\mathrm{R})}=\frac{X e-X i}{S i-S e} \mathrm{~K} \sin \frac{S i}{S e}+(\mathrm{Xe}-\mathrm{Xi})$

$\frac{\operatorname{acXaUmZ}}{\mathrm{Fo}(1+\mathrm{R})}=\mathrm{YK} \ln \frac{S i}{S e}+(\mathrm{Xe}-\mathrm{Xi})$

Let us recall that for a given substrate concentration $\mathrm{S}$, the rate of biodegradation is expressed thus:

$\frac{d s}{d t}=-{ }_{\beta} \mathrm{S}$

On separation of variables for integration, the above equation gives:

$\int_{S i}^{S e} \frac{d s}{S}=-\int_{0}^{t} \beta \mathrm{dt}$

Let $\mathrm{t}=\mathrm{T}$

$\ln \frac{S i}{S e}={ }_{\beta} \mathrm{T}$

Substituting (16) into (14) gives:

$\frac{\mathrm{acXaUmZ}}{\mathrm{YFo}(1+\mathrm{R})}=\mathrm{Ks}_{\beta} \mathrm{T}+\left(\mathrm{S}_{\mathrm{I}}-\mathrm{Se}\right)$

Assuming $\mathrm{Xa}=\mathrm{X}_{\mathrm{I}}$

$\mathrm{Se}=\left(\frac{-\mathrm{acXiUmZ}}{\mathrm{Y} \mathrm{Fo}(1+\mathrm{R})}+\mathrm{S}_{\mathrm{I}}\right)+\left(\mathrm{Ks}_{\beta}\right) \mathrm{T}$ 
Equation (17) is the Model equation for predicting the velocity (reaction rate) profile in terms of substrate concentration of a plug-flow fermenter.

Similarly, substituting (16) into (15) gives:

$\frac{\mathrm{acXaUmZ}}{\mathrm{Fo}(1+\mathrm{R})}=\mathrm{YKs}_{\beta} \mathrm{T}+(\mathrm{Xe}-\mathrm{Xi})$

Assuming $\mathrm{Xa}=\mathrm{X}_{\mathrm{I}}$

$\mathrm{Xe}=\left(\frac{\mathrm{acXiUmZ}}{\mathrm{Fo}(1+\mathrm{R})}+\mathrm{X}_{\mathrm{I}}\right)-\left(\mathrm{YKs}_{\beta}\right) \mathrm{T}$

Equation (18) is the Model equation for predicting the velocity (reaction rate) profile in terms of biomass concentration of a plug-flow fermenter.

\section{A. Computational Procedures}

The developed mathematical model was monitored, predicted and simulated by chosen simulation parameters as presented using MATLAB. All the chosen parameters used for this investigation are useful and necessary to enables' we determine functional coefficients that control the microbial and substrate interaction in a bioreactor with recycling mechanism.

\section{RESUltS AND DisCUSSION}

The results obtained from this investigation are presented in graph form with all computational parameters inputted in MATLAB as presented in the Figures shown below.

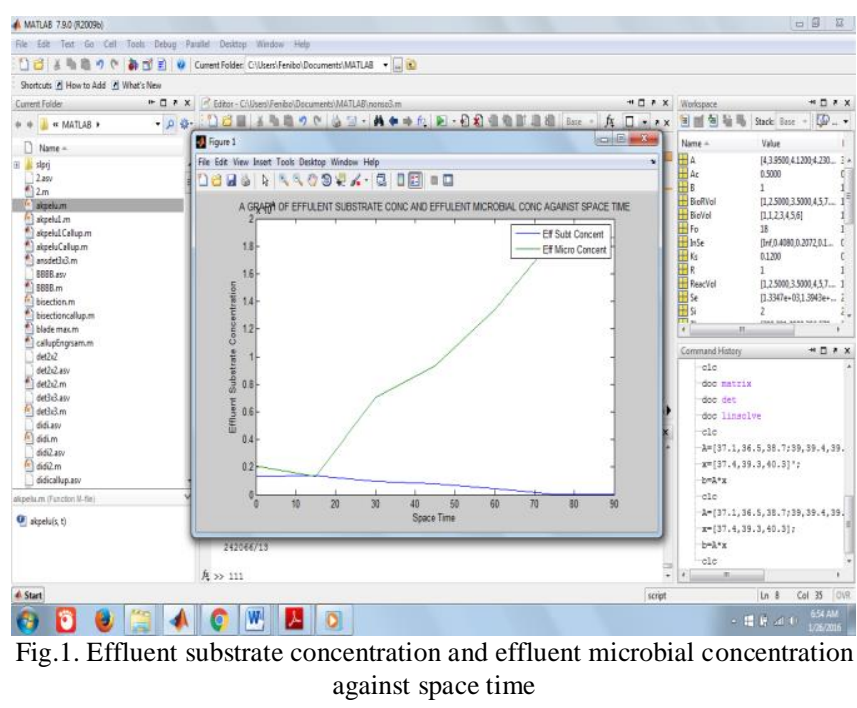

Fig.1 illustrates the interaction between the microbial and substrate in a bioreactor and result obtained shows increase in microbial concentration with decrease in substrate concentration with increase in space time. The variation in the microbial and substrate concentration can be attributed to the variation in the space time as well as other important factors that influence the bioreactor system.

The relationship between the effluent microbial concentration and the discharge time in the interaction of substrate and microbial concentration was investigated and result obtained revealed an increase in effluent microbial concentration with increase in discharge time as presented in Fig. 2. The variation in the effluent microbial concentration can be attributed to the variation in discharge time as well as functional parameters.

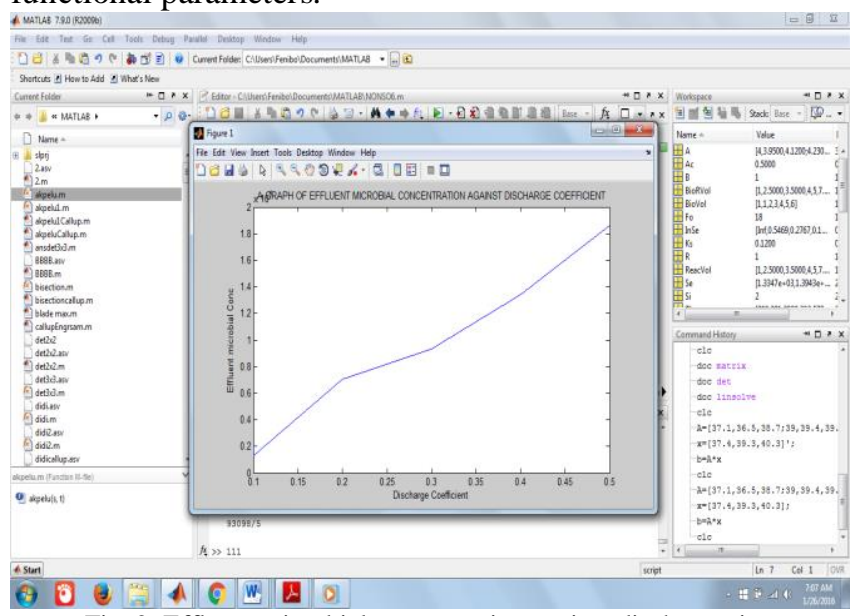

Fig. 2. Effluent microbial concentration against discharge time

Fig. 3 illustrates the characteristics of the effluent substrate concentration in a reactor volume and the results obtained revealed decrease in the effluent substrate concentration with increase in the reactor volume as monitored, predicted and simulated using MATLAB. The variation in the effluent substrate concentration can be attributed to the variation in the reactor volume as well as the functional parameters and coefficients. Similarly, it is seen from Fig. 4 that the substrate concentration decreases with increase in the bioreactor volume. The variation in the substrate concentration can be attributed to the variation in the bioreactor volume.

Fig. 5 illustrates the relationship between the effluent microbial concentration and reactor volume as well as increase in effluent microbial concentration was observed with increase in reactor volume. The variation in the effluent microbial concentration can be attributed to the variation in the reactor volume. Similarly, as presented in Fig. 6 it is seen that increase in microbial concentration was observed with increase in bioreactor.

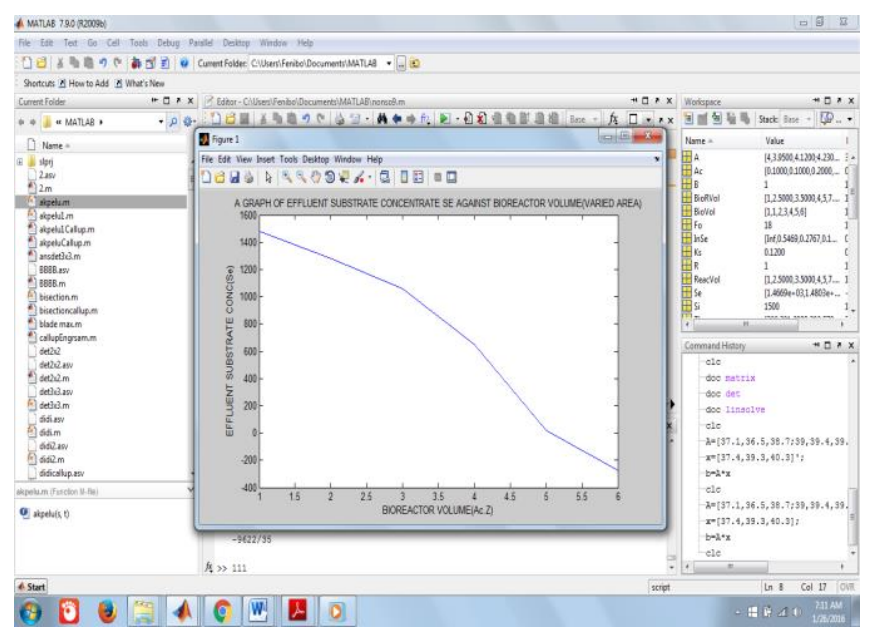

Fig. 3. Effluent substrate concentration against reactor volumne 


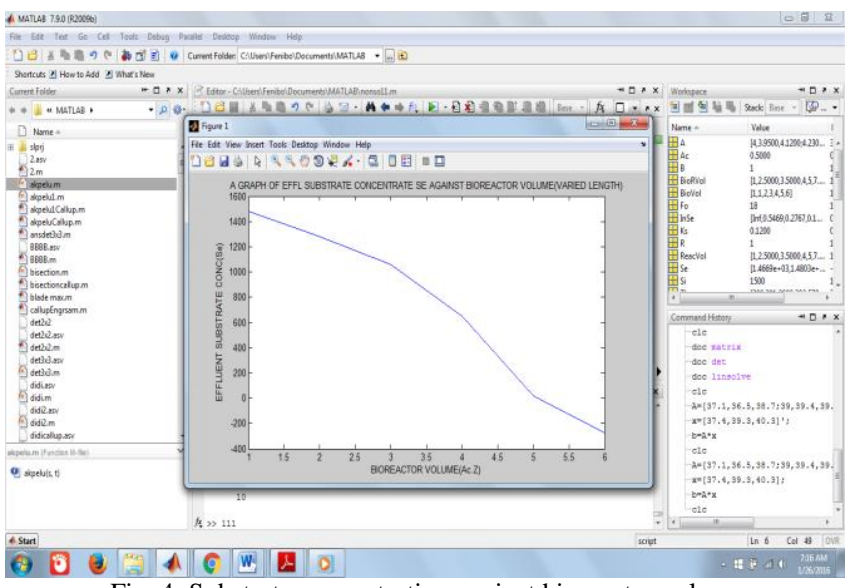

Fig. 4. Substrate concentration against bioreactor volume

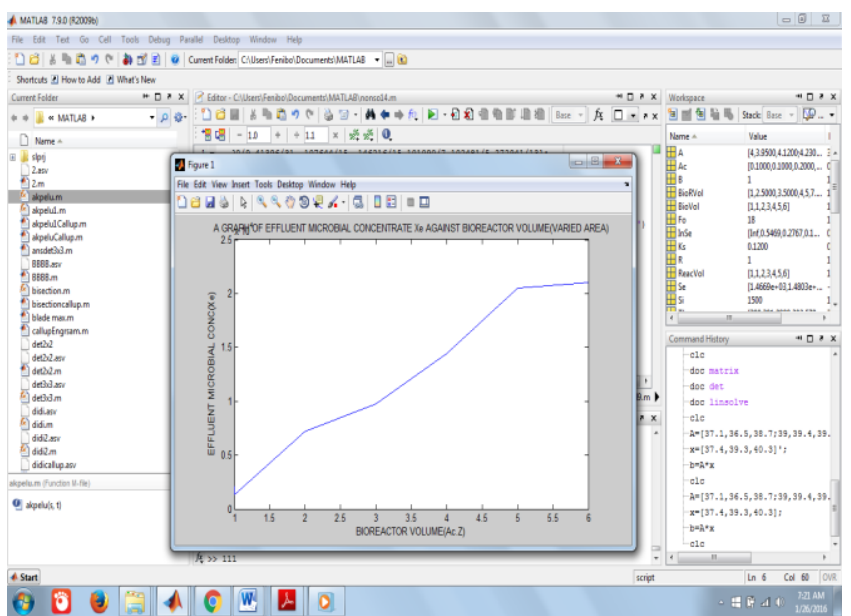

Fig. 5. Effluent microbial concentration against bioreactor volume

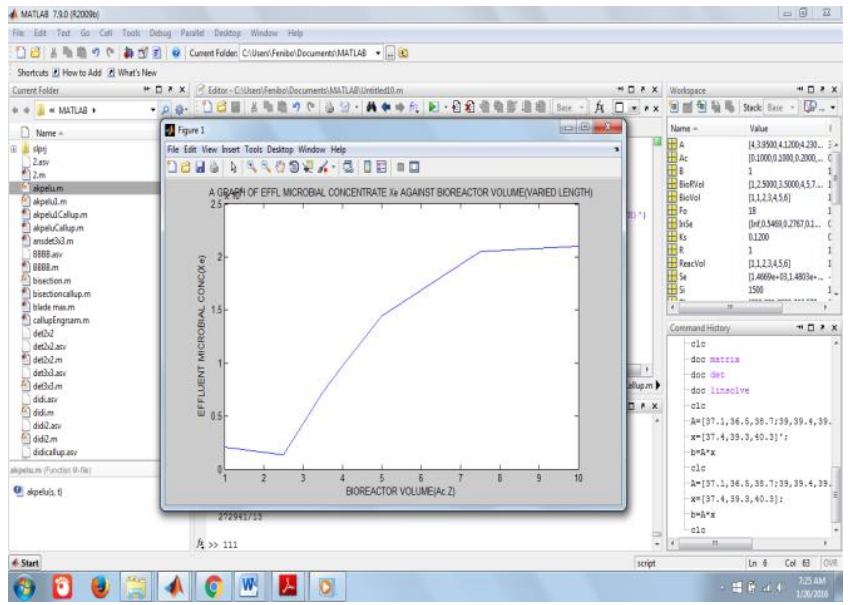

Fig. 6. Effluent microbial concentration against bioreactor volume

From the result obtained from the graph above, the substrate concentration across time increases while the microbial concentration decreases. As the reaction occur across different time interval, the substrate concentration tends towards maximum while the microbial concentration reduces to an insignificant level, thereby leading to an end in the reaction process.

It is also noted that, across the reactor volume, the substrate concentration decreases across the volume of the bioreactor, while the microbial concentration increases across the reactor volume.

\section{CONCLUSION}

Research conducted reveals the following observations:

1. It is observed that the volume of the reactor, the time of the reaction, the space velocity, discharge coefficients are variables that determines the nature and rate of the substrate and microbial concentration in a bioreactor.

2. The model equations to check their profile (substrate and microbial) has been developed and solved in this research work using MATLAB as the run out results are presented in the appendix.

3. Increase in microbial concentration without inhibitor yielded decrease in substrate concentration

4. MATLAB is a useful tool for monitoring, predicting and simulating the relationship between microbial and substrate utilization in a bioreactors system.

\section{APPENDIX}

The following are parameters used to simulate the graphs shown in Figs. 16 using MATLAB.

\section{For Fig. 1:}

$\%$ Modelling Of the Velocity Profile Of A Bioreactor with Recycle:

$\mathrm{Fo}=18 ; \% 1 / \mathrm{hr}$

$\mathrm{Um}=0.25 ; \% 1 / \mathrm{hr}$

$\mathrm{Ks}=0.12$;

$\mathrm{Y}=0.42$;

$\mathrm{R}=1$;

$\mathrm{Z}=10$;

$\mathrm{Ac}=0.5 ; \% \mathrm{~m} 2$

$\mathrm{B}=1 ; \% 1 / \mathrm{hr}$

for $\mathrm{Si}=[2000,1900,1800,1700,1650,1600,1500]$;

$\mathrm{Xi}=[2000,1300,6800,9000,13000,18000,18000]$

$\mathrm{V}=[0: 15: 90] ; \%$ SpaceTime

$\mathrm{Se}=\left(\mathrm{Si}-\left(\left(\mathrm{Ac}^{* \mathrm{Z}} * \mathrm{Xi} * \mathrm{Um}\right) /(\mathrm{Y} * \mathrm{Fo} *(1+\mathrm{R}))\right)\right)+(\mathrm{Ks} * \mathrm{~B}) * \mathrm{~V}$;

end

format rat

$\operatorname{disp}(\mathrm{Se})$

OUTPUT: Columns 1 through 6

$\begin{array}{lllll}42709 / 32 & 68322 / 49 & 61193 / 65 & 12943 / 17 & 12109 / 28\end{array}$

$439 / 21$

Column 7

2384/105

$\mathrm{Fo}=18 ; \% 1 / \mathrm{hr}$

$\mathrm{Um}=0.25 ; \% 1 / \mathrm{hr}$

$\mathrm{Ks}=0.12$;

$\mathrm{Y}=0.42$;

$\mathrm{R}=1$;

$\mathrm{Z}=10$;

Ac $=0.5 ; \% \mathrm{~m} 2$

$\mathrm{B}=1 ; \% 1 / \mathrm{hr}$

for $\mathrm{Si}=[100,100,80,50,15,5,2]$;

$\mathrm{Xi}=[2000,1300,6800,9000,13000,18000,18000]$;

$\mathrm{V}=[0: 15: 90]$;

$\mathrm{Xe}=\left(\mathrm{Xi}+\left((\mathrm{Ac} * \mathrm{Z} * \mathrm{Xi} * \mathrm{Um}) /\left(\mathrm{Fo}^{*}(1+\mathrm{R})\right)\right)\right)-(\mathrm{Y} * \mathrm{Ks} * \mathrm{~B}) * \mathrm{~V}$;

end

format rat

$\operatorname{disp}(\mathrm{Xe})$

Columns 1 through 6

$18625 / 9 \quad 63186 / 47 \quad 35173 / 5 \quad 121033 / 13 \quad 147932 / 11$

Column 7

242066/13

$\mathrm{Se}=[42709 / 32,68322 / 49,61193 / 65,12943 / 17,12109 / 28,439 / 21,2384 / 105]$ ;

$\mathrm{Xe}=[18625 / 9,63186 / 47,35173 / 5,121033 / 13,147932 / 11,167591 / 9$

,242066/13];

$\mathrm{V}=[0: 15: 90]$;

plot(V,Se, V,Xe)

xlabel('Space Time')

ylabel('Effluent Substrate Concentration') 
title('A GRAPH OF EFFULENT SUBSTRATE CONC AND EFFULENT MICROBIAL CONC AGAINST SPACE TIME')

legend('Eff Subt Concent','Eff Micro Concent')

\section{For Fig. 2:}

$\mathrm{Ac}=0.5 ; \% \mathrm{~m} 2$

$\mathrm{B}=1 ; \% 1 / \mathrm{hr}$

for $\mathrm{Si}=[2000,1900,1800,1700,1650,1600,1500]$;

$\mathrm{Xi}=[2000,1300,6800,9000,13000,18000,18000]$;

$\mathrm{V}=0: 15: 90$;

$\mathrm{p}=1 . / \mathrm{Si}$;

$\mathrm{q}=\left(\mathrm{Y}^{*} \mathrm{Fo}^{*}(1+\mathrm{R})\right)$

$\mathrm{r}=\left(\mathrm{Ac} * \mathrm{Z} \cdot \mathrm{Xi}^{*} \mathrm{Um}\right)$

$\mathrm{s}=1 /\left(\mathrm{Ks}^{*} \mathrm{~B}\right)$

$\mathrm{t}=1 . / \mathrm{V}$

$\mathrm{InSe}=(\mathrm{p}-(\mathrm{q} . / \mathrm{r}))+\mathrm{s} . * \mathrm{t}$;

end

format rat

$\operatorname{disp}(\operatorname{InSe})$

OUTPUT:Columns 1 through 6

$\begin{array}{lllll}1 / 0 & 2005 / 3666 & 843 / 3047 & 343 / 1859 & 365 / 2633\end{array}$

$2315 / 20836$

Column 7

$321 / 3467$

$\mathrm{Fo}=18 ; \% 1 / \mathrm{hr}$

$\mathrm{Um}=0.25 ; \% 1 / \mathrm{hr}$

$\mathrm{Ks}=0.12$;

$\mathrm{R}=1$;

$\mathrm{Z}=10$;

$\mathrm{Ac}=0.5 ; \% \mathrm{~m} 2$

$\mathrm{B}=1 ; \% 1 / \mathrm{hr}$

for $\mathrm{Si}=[100,100,80,50,15,5,2]$;

$\mathrm{Xi}=[2000,1300,6800,9000,13000,18000,18000]$;

$\mathrm{V}=[0: 15: 90]$;

$\mathrm{Y}=[0.1,0.1,0.2,0.3,0.4,0.5,0.5]$

$\mathrm{r}=1 / \mathrm{Ks} * \mathrm{~B}$

$\mathrm{Xe}=\left(\mathrm{Xi}+(\mathrm{Ac} * \mathrm{Z} * \mathrm{Xi} * \mathrm{Um}) /\left(\mathrm{Fo}^{*}(1+\mathrm{R})\right)\right)-\left(\mathrm{Ks}^{* \mathrm{~B}} * \mathrm{~V}\right) . \mathrm{Y}$;

end

format rat

$\operatorname{disp}(\mathrm{Xe})$

OUTPUT:Columns 1 through 6

$\begin{array}{lllll}18625 / 9 & 32279 / 24 & 161814 / 23 & 74487 / 8 & 26897 / 2\end{array}$

$37241 / 2$

Column 7

93098/5

$\mathrm{Y}=[0.1,0.1,0.2,0.3,0.4,0.5,0.5]$

$\mathrm{Xe}=[18625 / 9,32279 / 24,161814 / 23,74487 / 8,26897 / 2,37241 / 2,93098 / 5]$;

$\operatorname{plot}(\mathrm{Y}, \mathrm{Xe})$

xlabel('Discharge Coefficient')

ylabel('Effluent microbial Conc')

title('A GRAPH OF EFFLUENT MICROBIAL CONCENTRATION

AGAINST DISCHARGE COEFFICIENT')

For Fig. 3:

$\mathrm{Fo}=18 ; \% 1 / \mathrm{h}$

$\mathrm{Um}=0.25 ; \% 1 / \mathrm{hr}$

$\mathrm{Ks}=0.12 ; \% \mathrm{~g} / \mathrm{h}$

$\mathrm{Y}=0.42$;

$\mathrm{R}=1$;

$\mathrm{Z}=10 ; \% \mathrm{~m}$

$\mathrm{B}=1 ; \% 1 / \mathrm{hr}$

for $\mathrm{Si}=[2000,1900,1800,1700,1650,1600,1500]$

$\mathrm{Ac}=[0.1,0.1,0.2,0.3,0.4,0.5,0.6]$;

$\mathrm{Xi}=[2000,1300,6800,9000,13000,18000,18000]$

$\mathrm{V}=[0: 15: 90]$;

$\mathrm{Se}=(\mathrm{Si}+(\mathrm{Ks} * \mathrm{~B} \cdot * \mathrm{~V}))-\left(\left(\mathrm{Xi}^{*} \mathrm{Um}\right) /(\mathrm{Y} * \mathrm{Fo} *(1+\mathrm{R}))\right) . \mathrm{Ac}^{*} \mathrm{Z}$

end

format rat

$\operatorname{disp}(\mathrm{Se})$

OUTPUT:Columns 1 through 6

42541/29 53291/36 19181/15 $37064 / 35 \quad 11006 / 17$

$439 / 21$

Column 7

$-9622 / 35$

$\%$ Bio Reactor $\mathrm{Vol}$

$\mathrm{Z}=10$

$\mathrm{Ac}=[0.1,0.1,0.2,0.3,0.4,0.5,0.6]$

biovol=Z*Ac;

disp(biovol)

OUTPUT: Columns 1 through 6 $\begin{array}{llllll}1 & 1 & 2 & 3 & 4 & 5\end{array}$

Column 7,6

\%A GRAPH OF EFFLUENT SUBSTRATE CONCENTRATE SE AGAINST BIOREACTOR VOLUME

BioVol=[ 1,1,2,3,4,5,6];

$\mathrm{Se}=[42541 / 29,53291 / 36,19181 / 15,37064 / 35,11006 / 17,439 / 21,-9622 / 35]$ plot(BioVol,Se)

xlabel('BIOREACTOR VOLUME(Ac.Z)')

ylabel('EFFLUENT SUBSTRATE CONC(Se)')

title('A GRAPH OF EFFLUENT SUBSTRATE CONCENTRATE SE

AGAINST BIOREACTOR VOLUME(VARIED AREA)')

For Fig. 4:

\%Bio Reactor Vol GRAPH 7

$\mathrm{Ac}=0.5$;

$\mathrm{Z}=[2,5,7,8,10,15,20]$;

biovol=Ac. $*$ Z

disp(biovol)

OUTPUT:Columns 1 through 6

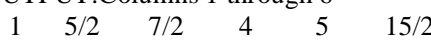

Column 7, 10

BioR Vol=[ 1,5/2,7/2,4,5,15/2,10];

$\mathrm{Se}=[42541 / 29,53291 / 36,19181 / 15,37064 / 35,11006 / 17,439 / 21,-9622 / 35]$

plot(BioVol,Se)

xlabel('BIOREACTOR VOLUME(Ac.Z)')

ylabel('EFFLUENT SUBSTRATE CONC(Se)')

title('A GRAPH OF EFFL SUBSTRATE CONCENTRATE SE AGAINST

BIOREACTOR VOLUME(VARIED LENGTH)')

\section{For Fig. 5:}

$\mathrm{Fo}=18 ; \% 1 / \mathrm{hr}$

$\mathrm{Um}=0.25 ; \% 1 / \mathrm{h}$

$\mathrm{Ks}=0.12 ; \% \mathrm{~g} / \mathrm{h}$

$\mathrm{Y}=0.42$;

$\mathrm{R}=1$;

$\mathrm{Z}=10 ; \% \mathrm{~m}$

$\mathrm{B}=1 ; \% 1 / \mathrm{hr}$

for $\mathrm{Si}=[2000,1900,1800,1700,1650,1600,1500]$;

$\mathrm{Ac}=[0.1,0.1,0.2,0.3,0.4,0.5,0.6]$

$\mathrm{Xi}=[2000,1300,6800,9000,13000,18000,18000]$

$\mathrm{V}=[0: 15: 90]$;

$\mathrm{Xe}=(\mathrm{Xi}-\mathrm{Y} * \mathrm{Ks} * \mathrm{~B} . * \mathrm{~V})+((\mathrm{Xi} * \mathrm{Um}) / \mathrm{Fo} *(1+\mathrm{R})) . * \mathrm{Ac} * \mathrm{Z}$

end

format rat

$\operatorname{disp}(\mathrm{Xe})$

OUTPUT:Columns 1 through 6

$18500 / 9 \quad 41396 / 31 \quad 107644 / 15 \quad 146216 / 15 \quad 101090 / 7$

$102481 / 5$

Column 7

272941/13

$\mathrm{Xe}=[18500 / 9,41396 / 31,107644 / 15$

146216/15,101090/7,102481/5,272941/13];

ReacVol=[1,1,2,3,4,5,6 ];

plot(ReacVol,Xe)

xlabel('BIOREACTOR VOLUME(Ac.Z)')

ylabel('EFFLUENT MICROBIAL CONC(Xe)')

title('A GRAPH OF EFFLUENT MICROBIAL CONCENTRATE Xe

AGAINST BIOREACTOR VOLUME(VARIED AREA)')

For Fig. 6:

$\mathrm{Fo}=18 ; \% 1 / \mathrm{hr}$

$\mathrm{Um}=0.25 ; \% 1 / \mathrm{hr}$

$\mathrm{Ks}=0.12 ; \% \mathrm{~g} / \mathrm{h}$

$\mathrm{Y}=0.42$;

$\mathrm{R}=1$;

$\mathrm{Z}=10 ; \% \mathrm{~m}$

$\mathrm{B}=1 ; \% 1 / \mathrm{hr}$

for $\mathrm{Si}=[2000,1900,1800,1700,1650,1600,1500]$;

$\mathrm{Ac}=[0.1,0.1,0.2,0.3,0.4,0.5,0.6]$;

$\mathrm{Xi}=[2000,1300,6800,9000,13000,18000,18000]$;

$\mathrm{V}=[0: 15: 90]$;

$\mathrm{Xe}=\left(\mathrm{Xi}-\mathrm{Y}^{*} \mathrm{Ks}{ }^{*} \mathrm{~B} . * \mathrm{~V}\right)+\left((\mathrm{Xi} * \mathrm{Um}) / \mathrm{Fo}^{*}(1+\mathrm{R})\right){ }^{*} \mathrm{Ac} * \mathrm{Z}$

end

format rat

$\operatorname{disp}(\mathrm{Xe})$ 
OUTPUT:Columns 1 through 6

$\begin{array}{llll}18500 / 9 & 41396 / 31 & 107644 / 15 & 146216 / 15 \\ 101090 / 7 & 102481 / 5 & \end{array}$

Column 7

272941/13

Vol=[ $1,5 / 2,7 / 2,4,5,15 / 2,10]$;

$\mathrm{Xe}=[18500 / 9,41396 / 31,107644 / 15,146216 / 15$

,101090/7,102481/5, 272941/13];

plot $(\mathrm{Vol}, \mathrm{Xe})$

xlabel('BIOREACTOR VOLUME(Ac.Z)')

ylabel('EFFLUENT MICROBIAL CONC(Xe)')

title('A GRAPH OF EFFL MICROBIAL CONCENTRATE

Xe AGAINST BIOREACTOR VOLUME(VARIED

LENGTH)')

\section{REFERENCES}

[1] S. A. Amadi, and C. P. Ukpaka, Evaluation of corrosion behavior of pipeline steel structure in onshore environment. Physical Chemistry Pakistan, vol.17, no. 1, pp. 21 - 26, 2015.

[2] S. A. Amadi, and C. P. Ukpaka, Role of molecular diffusion in the recovery of waterflood residual oil. International Scientific Organization: Chemistry International, vol. 2, no. 2, pp. $103-114$, 2016.

[3] S. A. Amadi, and C. P. Ukpaka, Petrochemical effluent on pollution monitoring, International Journal of Environmental Science and Toxicology, vol. 2, no. 1, pp. $16-21,2014$

[4] S. A. Amadi, and C. P. Ukpaka, Evaluation of corrosion resistance and behaviour of construction material exposed to acidic environment at elevated temperature under static condition, International Journal of Novel Research in Engineering and Pharmaceutical Science, vol.1, no. 4, pp.11-23, 2014.

[5] S. E. Ejejigbe, and C. P. Ukpaka, Evaluation of chemical finger printing of individual crude oil from Nigeria. CASRP Journal of Applied Sciences, vol. 1. no.2, pp. 78 -94, 2015

[6] S. E. Ejejigbe, and C. P. Ukpaka, Studying the n-alkanes profile of the mussels on Nigeria crude oil contamination. International Journal of Novel Research in Engineering \& Pharmaceutical Sciences, vol. 2, no. 03 , pp. $62-70,2015$.

[7] S. E. Ejejigbe, S. A. Amadi, and C. P.Ukpaka, Evaluation of Polycyclic Aromatic Hydrocabons (PAHs) distribution profile and concentration ratio on Nigeria crude oil, International Journal of Novel Research in Engineering \& Pharmaceutical Sciences, vol. 2, no. 03 , pp. $71-84,2015$

[8] S. E. Ejejigbe, S. A. Amadi, and C. P Ukpaka, Evaluation on the geochemical biomarkes of Nigeria crude oil. CASRP Journal of Applied Sciences, vol. 1. no. 2, pp. 64 -77, 2015.

[9] P. N. Ikenyiri, and C. P. Ukpaka, Mathematical model to monitor the inhibiting effect of $\mathrm{pH}$ on the adsorption of crude oil in bioremediation, Scholars Research Library: Archives of Applied Science Research, vol.6, no.6, pp. 40-45, 2014.

[10] C. P. Ukpaka, Modeling the sinusoidal characteristics of Dry Season Momentum Transfer in Biodegradation of petroleum Hydrocarbon in Pond system. International Journal of Current Research, vol. 4, no. 2, pp. 131-138, 2012

[11] C. P. Ukpaka, Sodium chloride Concentration on the Rheological and Dynamic Properties of Aloe-Vera Gel. Journal of Engineering and Technology Research vol.4, no.7, pp.136-148, 2012

[12] C. P. Ukpaka, Application of polynomial method to monitor and predict the Aromatic hydrocarbon degradation pseudomonas $\mathrm{sp}$ Comprehensive Research Journal of Biological Science (CRJBS), vol. 1, no.1, pp.006-020, 2013.

[13] C. P. Ukpaka, Studying the depuration time on changes in biomarkers profile on Nigeria crude oil. Applied Science Reports, vol. 13, no. 2, pp. $69-74,2016$.

[14] C. P. Ukpaka, The effect of Substrate Characteristics Medium on Improvement of MEOR in Niger Delta Area of Nigeria. International Journal of Current Research, vol,4, no. 1, pp 100-110, 2012.

[15] C. P. Ukpaka, and J. Chuku, Investigating the Physiochemical Parameters and the Portability of some river Water in Rivers State of Nigeria. Journal of Research in Environment science and Toxicology, vol.1, no. 2, pp. 168-185, 2012

[16] C. P. Ukpaka, and I. Edwin, Adsorbent in bioremediation of crude oil polluted environment influence of physiochemical characteristics of various saw dusts. International Research Journal of Biotechnology, vol. 4 , no. 6 , pp. $68-75,2013$.
[17] C. P. Ukpaka, J. Odharo, and C. Akpado, Conventional Analysis of Equipment failure in Olefin Plant. International Journal of Current Research, vol. 4, no. 2 pp.122-130, 2012.

[18] C. P. Ukpaka, H. A Ogoni, S. A.Amadi, J. A. Akor, Wet season predictive techniques for monitoring the hydrocarbon degradation in a continuous discharge of wastewater in pond system. Journal of modeling simulation and control, vol.71, no.1, pp.62-80, 2010.

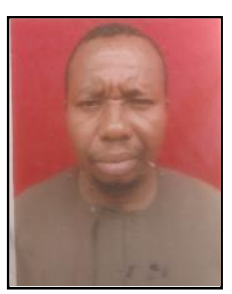

Chukwuemeka P. Ukpaka was born in Obite Town, Ogba/Egbema/Ndoni Local Government Area of Rivers State, Nigeria. I was born on $24^{\text {th }}$ December, 1969. He had his bachelor of Technology degree in Chemical/Petrochemical Engineering from Rivers State University of Science and Technology Port Harcourt, Nigeria in 2000; Master of Technology in Chemical Engineering in the field of Biochemical environment Engineering - Remediation Technology from the Rivers State University of Science and Technology Port Harcourt, Nigeria in 2004; PhD in Chemical Engineering in the field of Modeling and Simulation of Chemical Interaction with Biochemical Process Engineering (Bioremediation option the concept of Momentum influence in Pond system) from Rivers State University of Science and Technology Port Harcourt, Nigeria in 2009. His major field of study is Chemical and Biochemical Environmental Engineering.

He was currently promoted to the rank of Reader (Associate Professor) and in the Department of Chemical/Petrochemical Engineering in Rivers State University of Science and Technology Port Harcourt, Nigeria. He is emotionally stable and focused in academic research as well has published several articles both local and international journals in the following: International Journal of Environmental Science and Toxicology (IJEST), American Multidisciplinary International Research Journal (AMIRJ), International Journal of Novel Research in Engineering \& Pharmaceutical Science (IJNREPS), Association for the Advancement of Modelling \& Simulation Techniques in Enterprises (AMSE), The Canadian Journal of Chemical Engineering, International Journal of Science and Technology (IJSE), Nigerian Journal of Research and Production, Multidisciplinary Journal of Empirical Research, Journal of the Nigerian Society of Chemical Engineers etc. His research interest is on modeling and simulation of chemical and biochemical engineering processes as well as environmental engineering.

Dr. Ukpaka is an active member of several profession bodies, such as, Council for the Regulation of Engineering in Nigerian (COREN), Nigerian Society of Engineers (NSE), Nigerian Society of Chemical Engineers (NSChE), Fellow in Strategic Institute for Natural Resources and Human Development (SINRHD), International Research and Development Institute (Research and Development Network). He has several awards such as Pinnacle award presented by Nigerian Society of Chemical Engineering (A Division of Nigerian Society of Engineers NSE on International Conference and Exhibition of $44^{\text {th }}$ Annual General Meeting and Conference Owerri, 2014. He is a reviewer and editorial board member of several journals such as International Journal of Environmental Science and Toxicology (IJESI), World Journal of Biology and Medical Science (Honorary Regional editor), American Multidisciplinary International Research Journal, International Journal of Novel Research in Engineering and Pharmaceutical Sciences etc.

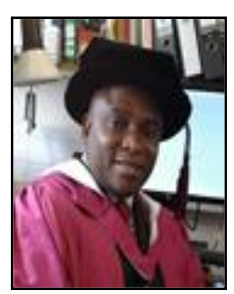

Sunny Orike was born in Osiakpu village, Ogba/Egbema/Ndoni Local Government Area, Rivers State, Nigeria, on $21^{\text {st }}$ July, 1974. He had his Bachelor of Technology degree in Computer Engineering from Rivers State University of Science and Technology, Port Harcourt, Nigeria in 1998; MSc in Computing (Software Technology) from Robert Gordon University, Aberdeen, United Kingdom, in 2003; MPhil. In Computational Intelligence from Robert Gordon University, Aberdeen, United Kingdom, in 2008; and $\mathrm{PhD}$ in Artificial Intelligence from Heriot-Watt University, Edinburgh, United Kingdom in 2015. His major field of study is computer engineering.

$\mathrm{He}$ is currently the Head, Department of Electrical/Computer Engineering, Rivers State University of Science and Technology, Port Harcourt, Nigeria. He is an enthusiastic, articulate, focused, self-motivated, goal-oriented and excellence-driven engineer, with vast experience spanning across teaching, administration and research. His papers have been published in reputable academic journals and peer-reviewed conference proceedings, including British Journal of Science, Asian Engineering Review, International Journal of Computer Applications, Journal of Engineering and Applied Sciences, IEEE Digital Library, amongst others. His research interests are in the areas of Software Engineering, Artificial/Computational Intelligence, and Electrical Power 
System Optimization.

Dr. Orike is an active member of several professional bodies, including: Council for the Regulation of Engineering in Nigeria (COREN), Computer Professionals Registration Council of Nigeria (CPN), Nigerian Society of Engineers (NSE), Nigeria Computer Society (NCS), British Computer Society (BCS), Institute of Electrical Electronic Engineers (IEEE), Nigeria Institution of Electrical Electronic Engineers (NIEEE), Association of Computing Machinery (ACM) and International Association of Engineers (IAENG). He also acts as a reviewer to several journals, including: Journal of Applied Soft Computing, Journal of Control and Intelligent Systems, International Journal of Electrical Power and Energy Systems, Journal of Computer Science and its Applications, amongst others

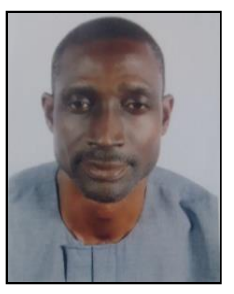

Felix U. Igwe was born in Obukegi village, Ogba/Egbema/Ndoni Local Government Area, Rivers State, Nigeria, on March 30, 1966. He obtained the Bachelor of Science (BSc) degree in Chemistry (Biochemistry option) from Rivers State University of Science and Technology, Port Harcourt, Nigeria, in 1986; Master of Science (MSc) degree in Biochemistry from University of Port Harcourt, Port Harcourt, Nigeria, in 1994; Post Graduate Certificate in Drilling and Workover Fluids Technology from Baroid Training Centre (now Halliburton University), Houston, Texas, USA, in 1998 and PhD in Environmental Toxicology Management from Rivers State University of Science and Technology, Port Harcourt, Nigeria, in 2009. His major field of study is Biochemistry.

$\mathrm{He}$ is currently a Senior Lecturer in the Department of Biochemistry, Rivers State University of Science and Technology, Port Harcourt, Nigeria. $\mathrm{He}$ is a calm, self-motivated, result-oriented research scientist with vast experience spanning across teaching, research, administration and drilling fluids engineering. His papers have been published in reputable peerreviewed academic journals including; AMBIO, Journal of Nigerian Environmental Society, Journal of Applied Science and Environmental Management, Journal of Biotechnology Research, amongst others. His research interest is in the areas of Environmental Toxicology, Occupational Toxicology, Bioreactor Optimization and Pollution Control

Dr. Igwe is an active member of several professional bodies including; Chemical Society of Nigeria (CSN), Institute of Chartered Chemists of Nigeria (ICCON), Society of Petroleum Engineers (SPE), Nigerian Environmental Society (NES) and Registered Environmental Specialists (RES). He also acts as a reviewer to several journals including: Journal of Environmental Research and Public Health. 